\title{
What can scientists contribute to arms control?
}

ARMS control and disarmament have had an unexpectedly active summer. Not that anybody has actually done anything about controlling arms or putting them out of harm's way, but there has been more public talk than for a long time. Daedalus has followed up, fifteen years on, its immensely valuable Fall 1960 issue on arms control with a Summer 1975 issue devoted to "Arms, Defense Policy, and Arms Control." The World Federation of Scientific Workers (WFSW) has recently held a major symposium ("The role of scientists and of their organisations in the struggle for disarmament") in Moscow. And the thirtieth anniversary of Hiroshima has occasioned some thought-provoking events, particularly (on BBC Television) a remarkable interview with Professor Philip Morrison who gave a lucid description of the way things were and the way people thought in those days.

There has been a nice contrast about it all; the harsh realities of Morrison, the populist aspirations in Moscow, the purring sophistications of Cambridge, Massachusetts. But have science and the scientist any future in the field of arms control? The WFSW has no doubt; "scientific workers can provide the ammunition to make the force of public opinion [for ending the arms race] overwhelming". Daedalus is less sure: ". . . arms control and disarmament now appear to be politically more complex than they did in 1960, while the technical aspects (of verification and the like) appear somewhat less complicated and perhaps therefore less consequential", writes Franklin Long.

The similarities between atomic weapons and arms control are striking. There was a time when certain key scientists could make direct approaches to politicians and be given a fair hearing for their views on whether and how a bomb should be built. But once government had been told how to do it, a large machine took over and nuclear weapons became no longer a crusade but an industry. So it was with arms control. There was a time when scientists had governments' ears for their views on verification; a black box here, Mr President, a satellite there, two dozen seismometers here. There were heady times, as many will testify, when it really looked as if significant nuclear limitations might have been negotiated on the basis of straightforward technical advice. No longer; the scientists gave what they knew, the machine of state absorbed it and moved on. Even arms control became less of a crusade and more of an industry.

It also became infinitely more complex, of course.
Whereas it used to be possible to talk of banning this or that, it is now necessary to deal in packages; restricting (not banning) this or that, swapping information on space medicine and wheat yields, exchanging works of art, making visas easier to get and so on. The scientist's role as an input of scientific information is a pretty minor one and at least in the nuclear field is likely to remain so.

It has also to be remembered that for every one scientist who sincerely deems it his or her responsibility to speak out in the few forums available (in the UK practically none at all, since the community of intellectuals is otherwise preoccupied) there is at least one other scientist who deems it his or her responsibility to work diligently to keep the nation's defences intact. Thus talk of Hippocratic oaths for scientists to eschew work on projects which might injure or kill humans or calls for scientists to measure up to their social responsibilities might, if taken seriously, lead to holier-than-thou witch-hunts in the scientific community.

If one cannot be optimistic that scientists per se have a major role to play in arms control discussions in general, there are perhaps two areas in which they can be particularly effective. The first includes weapons of the twenty-first century (perhaps, in particular, environmental weapons). Since none of these are at the research and development stage yet, there is likely to be a much greater agreement that they should be eschewed. Scientists are notoriously conservative in predicting the future of their subject, but surely if a major international effort were to be devoted to identifying danger areas, it is not inconceivable that an international consensus could be reached on control measures before rather than after the threat was in existence. Second, scientists could make a ruthless examination of the research and development aspects of every proposed arms control measure and ensure the appropriate publicity.

- Research and development is the mainspring of military improvement; beware of any agreement that leaves the laboratories intact.

- The Partial Test Ban Treaty was even used as a justification for the United States to increase its nuclear research and development activities.

- SALT has been a positive encouragement to qualitative improvement of missiles.

Nobody knows this as well as the informed scientist, and it may on occasions even be necessary for apparently benign measures to be opposed. 